\title{
LOCAL GOVERNMENT AND THE CONSTITUTION: THE NIGERIAN EXPERIENCE
}

https://doi.org/10.47743/jopafl-2021-22-25

\author{
Adebayo T. SALAMI \\ Department of Political Science \\ Olabisi Onabanjo University \\ Ago-Iwoye, Nigeria \\ salami.adebayo@oouagoiwoye.edu.ng
}

\begin{abstract}
What is or should be the research relationship between local government and the constitution? How can the research relationship be explored? What should be the investigative parameters and criteria? Put more directly, what form of relationship exists or should exist between local government and the constitution? How can the relationship be investigated? Of more fundamental necessity, is there any justification to investigate the relationship? Consequently, of what relevance is the study of the relationship to scholarship? The questions are crucial to both the understanding of the theory and practice of federalism and to the specialty, local government studies in Nigeria in particular. Apart from assisting in creating scholarly avenues for a profound study of power interplays in federally organized systems, part of the objectives of the paper is to as well place the Nigerian experience under close scrutiny and perhaps use it to generate issues and problems of comparative research that would in turn impact tremendously on generalization and theory building within the sub-field and specialty. Data sources are secondary and this can be justified by the nature of the research topic and the attendant core/research questions. This mode of analysis is descriptive, qualitative, historical and philosophical. Most likely arising from the existence of paucity of materials on the study of the relations up between local government and the constitution, the paper suggests that the existing perspective especially as pioneered by Gboyega (1981), be reinforced with a concrete focus on the problematic issue of judicial interpretation within established social science research rules and methodology.
\end{abstract}

Keywords: Local Government. Constitution

\section{Introduction}

What are the theoretical and empirical relationships between local government and the constitution? Within what intellectual outlook should the study of the relationship be based? Put more directly, how is the constitution and local government related? Has the relationship any specific character and or form? What is the basis of the relationship? And how can the basis are explained? All the questions try to examine the critical issues in the idea of local government, and how the idea can in turn foster development. Beyond this, there is the need to provide the necessary intellectual basis for discussing local government within the broad framework of the constitution, a neglected area of research in local government studies. It is hoped that the discussion here engaged will help to advance discourse on local government beyond the theoretically and politically mundane matters to issues of critical substance in law and political theory, the supposed foundations of local government thoughts. Again, how should the subject (local government and the constitution) be approached? This is indeed a very big question. Notwithstanding, the investigation will no doubt benefit from comparative analyses and disquisitions. The 
apposite question remains: What is the comparative import of the Nigerian experience? Nigeria, it is here argued, provides fascinating experience, especially given the tardiness of her developmental directions, and the uniqueness of her party politics. It is perhaps the only country in the world where a Constitution was prepared (1999 Constitution), but was never put to use. It is perhaps also the only country in the world where violations of constitutional provisions (in relation to the structure and operations of the local government) are taken as normal, and therefore not queried with perhaps the recent action of the "elected" local government executives in Oyo State (prelude to hand over date of May 29, 2007), who decided to challenge their dissolution in court by Mr. Adebayo AlaoAkala, the Executive Governor of Oyo State, Nigeria. The legal battle, one recalls, is still on and therefore there is little that can be said for now.

The constitution of any country is usually the fundamental legal charter of the country. It is considered as the fundamental legal charter because it defines the framework of government, and goes ahead to specify the structure of governmental operations and processes. As argued by Kenneth C. Wheare (1953), it is an essential precondition of the "federal principle". Multiple as these preconditions are, the striking difference remains the cumbersomeness in its amendment procedures and hence the characterization, rigid and flexible constitutions. The postulate by Wheare leads one to ask the question: Is local government indeed a third-tier level of government so recognized by the constitution? To what extent is this characteristic of federal system, and what is the extent of variation and compliance? Beyond defining the framework of government, the constitution gives power to every tier of government and goes ahead to provide a limitation as well. To what extent does the Nigerian constitution give political power to local government, and what is the amount of power that is so given? In other words, to what extent does the constitution recognize local government as a tier of government? How is this recognition protected, and by what enabling instruments? Answers to these and other questions shall constitute the preoccupation of the paper. Towards this end, the paper is divided into the following parts. Part one focuses on further elaboration of the relationship between local government and the constitution from the perspective of federalism. Part two provides a historicaldevelopment perspective to the issues raised in the theoretical elaboration, while part three discuss the implication of the Nigerian experience on standard comparative research methodology. Part four provides the conclusion.

\section{Local Government and the Constitution: Further Theoretical Substantiation and Exploits}

How can the theoretical (philosophical) relationship between local government and the constitution be further substantiated and or expatiated? This requires an in-depth probe into the meaning of federalism. In other words, any justification and or elaboration of the relationship between the two require deep and profound study of federalism. This is so because only in relations to federalism can the relationship be properly understood in its logical and empirical contexts. The position, no doubt, seems to neglect the fact that local government and the constitution (especially the relationship between the two) are also common to unitary systems, but the standard test of the status of the local government as recognized and provided for in the constitution and law can only be adequately and sufficiently tested within the federal framework of government, one humbly submits. 
The reading of federalism from the classical perspective suggests to one that it is all about the sharing and allocation of political powers in such a way that the composite units remain independent and yet coordinate. Surprising enough, the classical understanding of federalism is of limited value to the ongoing analysis. This is because the federalists concerned themselves with power relations between the centre and the States to the detriment of the local government. The local government was least thought of it in the growth and development of federalism as a philosophy of governmental organization. It is only consequential today that federal constitutions expect the States to make laws for the structure, organization and operations of the local government. This is indeed a major limitation to the task of examining the relationship between the local government and the constitution, as every initial/pioneering effort was targeted only at defending the States from the likely excesses of the central government as envisaged.

The connection and or relationship between local government and the constitution can be looked at from three principal angles. These angles are (a) the extent to which the constitution serves as the source of political power for the local government, or the extent to which we can say that the local government derives its existence (legally and politically) from the constitution, (b) the extent to which the sources of its funding are defined clearly by the constitution, and (c) the extent which its relationships with other tiers of government is either defined or provided in the constitution.

As Source of Political Power: Just like other tier of government, the local government derives its power from the constitution. This remains a basic feature of all constitutional democracies, irrespective of its structure of government. However, typical of federal constitutions, such constitutions specify in clear terms the powers and limitations of every tier of government, including the local government.

Fund Generation and Taxation: The constitution does not only define the powers of local government in relation to other tiers of government, it goes further to provide for local government its revenue sources and how such can be maximally tapped. Such include tenement rates, hackney permits, etc, as internal revenue sources and allocation from the federation accounts, grants, etc, as external revenue sources.

Inter-governmental Relations: The constitution is not only basic to federal systems of government, in particular a written one, it as well defined intergovernmental relations. The relationship among local governments (local-local), between local governments and the States (state-local), among the States (state-state), and between the States and the federal (federal-state), among others, are explicitly provided for in the constitution and properly defined as well.

The question that is apposite is: What is the intellectual basis and or rationalization for these relationships as provided for in most constitutions: federal and unitary, especially the former? The answer to this can be instantly looked at from the theory of separation of powers, and the principle of checks and balances. The choice of the latter can again be justified by the hope which democracy provides as the lesson learned from the collapse of the ancient regimes arising principally from the concentration of political powers in either one individual or a selected few. While the theory of separation of powers addresses or prevents most likely, the evil that might attend the concentration of powers in one organ of government, and the principle of checks and balances ingenuously provide a mechanism through which power is used to check power, their relationship to the question raised explains also the reason d'être and or justification of federalism. Those who believe in 
States rights, especially at the inception of American federalism, had argued for the need to protect State and local governments from the expected over-bearing influence of the central or national government. It was as well hoped that democracy would not only ensure the protection of rights (through majority rule decision), it would as well ensure a systematic order in the way in which rules are applied within the generally accepted principle of constitutionalism or supremacy of the constitution.

The link between local government and the constitution can hence be most forcefully explained within what in literature is regarded to as "the theory of local government". In other words, the appreciation of the intellectual basis in which the link between local government and the constitution is constructed can as well be critically looked at from the associated normative constructs and or exploits in political theory. The political theory of local government attempts to put forward some kinds of rationalization for its existence in the standard fashion of intellectual rigour and sophistication best represented in the works of J.S. Mill (1975), C.F Wilson (1948), K. Panter-Brick (1954), W.J.M. Mackenzie (1961), L.J. Sharpe (1961), among others.

Since local government is thought to be of importance in building democracy and in making of rational choices, it is considered as well that it (local government) be effectively protected by the constitution, especially in extremely divided societies. As the engine of democracy and the closest avenue of reaching the people, local government powers need also be properly defined within the overall framework of whole system governance, especially as population growth keeps increasing, and as cities and towns grow in endemic urbanization problems.

\section{Local Government and the Constitution: The Nigerian Experience}

The Nigerian experience is here examined from three republican constitutions. These are the 1963, 1979 and 1999 constitutions.

\section{The 1963 Republican Constitution}

Before the attainment of independence in 1960, there was what one can call a disjointed system of local government operation in Nigeria. As disjointed as the system then was, it was yet characterized by colonial integration of the variegated cultures. The three regions (the West, East, and North) had different legislative enactments, all serving the purpose of colonialism within the administrative framework or policy of "indirect rule". The 1963 Constitution was indeed a federal constitution in the true sense of the term, Section 86 of it provides that: "The executive authority of a Region shall extend to the execution and maintenance of the constitution of the Region and to all matters with respect to which the legislature of the Region has for the time being power to make laws but shall be so exercised as not to impede or prejudice the exercise of the executive authority of the federation or to endanger the continuance of federal government in Nigeria”. Section 2 further provides that: "Nigeria shall be a federation comprising regions and a federal territory and shall be a Republic of the Federal Republic of Nigeria”. It is as well contained in the constitution, Section 3 (1) and (2) that: "There shall be four regions, that is to say, Northern Nigeria, Eastern Nigeria, Western Nigeria and Mid-Western Nigeria; "the Regions and the Federal territory shall consist of the areas comprised in those territories respectively on the thirtieth day of September, 1963”. From the above, what is made clear 
in the constitution is that the local government is not legally recognized as a tier of government even though the constitution is clear on the fact that Nigeria is a federal system of government. As the 1963 constitution is clear on the fact that Nigeria is a federal system of government. As the 1963 constitution divided powers between the federal and the regions in the schedule under the caption, "The Legislative List", "The Executive Legislative List", and "The Concurrent Legislative List", the local government was at least considered let alone assigned some functions to perform. The conclusion that can be arrived at is that local government under the 1963 constitution was not a tier of government in the strict legal application and terminology.

\section{The 1979 Constitution}

The processes that led to the framing of the 1979 constitution are already well documented by Gboyega (1979). It is however, significant to note that for the first time in the history of Nigeria, local government (in name and constitutional responsibilities) was embedded in a comprehensive legal documentation in both theory and practice, especially as the theory and practice relate to the "federal principle". This of course can be traced to the 1976 Local Government Reform, in particular it's associated "Guidelines". Local Government is explicitly provided for in chapter one, part two of the 1979 Constitution. Section 7 (1) of the constitution declares unequivocally that: "The system of local government by democratically elected local government councils is under this constitution guaranteed: and accordingly, the Government of every State shall ensure their existence under a law which provides for the establishment, structure, composition finance and functions of such councils. Subsections 1,2,3,4,5 and 6 equally addresses fundamental issues relating to the creation, area delimitation, public revenue sharing and the role of the local government in economic development planning, among others. Part one of the first schedule of the 1979 Constitution did not only mention the number of States in Nigeria, but also the number of local governments per each state of the federation. The ideas were indeed novel.

\section{The 1999 Constitution}

The 1999 Constitution, present constitution which Nigeria operates, also in Section 7, like that of the 1979 constitution, word for word, recognizes: "The system of local government by democratically elected local government councils..,” Other critical issues of creation, boundary or area delimitation, role in economic development planning, among others, are equally addresses like in the 1979 constitution, in section 7, subsection 2,3,4,5 and 6. It is not just enough in the paper to undertake a cursory examination of the relationship between the local government and the constitution by only looking at the extent to which the 1963, 1979 and the 1999 Constitutions either attempted to recognize local government as a tier of government within the Nigerian federal framework, or determine the extent to which the various constitutions give recognition to the need for local government. It will, here reasoned, and within the context of informed scholarship, be worthwhile if we can as well engage ourselves with the extent of compliant to the provisions of the constitution and in the process determine the contemporary relevance of the federal alternative to Nigeria. Accepted that the local government was least thought of in the 1963 constitution, the 1979 and 1999 constitutions remain ineffective legal instruments in meeting the 21st century needs and challenges of the local government in 
Nigeria. What is provided for in the 1999 Constitution is a "system of local government by democratically elected local government councils...”. But the question can be asked: To what extent is the Nigerian local governments a system, and to what extent too is it governed by "democratically elected local government councils...”? The two questions in one require elaborate details. The idea of "system", here conceived, is based on the Estonian understanding of "political system" and the Parsonian understanding of "social system”. But from the restricted view of administrative coinage which serves immediate use here, the Nigerian local government is far from being a system of coordinating parts. It is rather totally disjointedly, unorganized and faulty. It is however, important to recall that the 1976 Local Government Reform, fired by the exemplary leadership character of General Murtala Ramat Mohammed, attempted for the first time to provide an integrated framework of local government system in Nigeria. The corruption of the civilian government of the Shehu Shagari and that of the military administration that later followed, destroyed to the very foundation the philosophy that informed the famous 1976 local government reorganization.

While the 1999 Constitution empowers Electoral Commissions at the State level to organize elections into the local government councils, this can only be done if the Independent National Electoral Commission (INEC), a national/federal executive body, supplies the State's Electoral Commission with the List of Registered Voters. This practically means that elections into the local government council can only take place at the behest of the Federal Government as the Independent Electoral Commission is only Independent in name. With the legitimacy crisis which the entire 2007 General Elections placed on the present administration of President Umar Musa Yar'adua, the hope of a quick dismemberment of the present caretaker committees and their replacement by a democratically elected local government council deems day by day. In some States of Nigeria, caricatures and or resemblances of democratic arrangements were (and still are) crafted without the electorates having significant inputs into these arrangements as elections were allegedly rigged and the outcomes of judicial verdict very contradictory even when matters of evidence are similar in their presentations.

Significantly too, the provision of the law says that ten percent of internally generated revenue of the States be made available to the local government only exists in theory. The practice is that the States, through the Joint Account which they maintain with the local governments, an account whose creation is also supported by law, siphon most of the revenues that otherwise should have accrued to the local governments, partly due to the stinking corruption, and partly due to the overbearing influence of the State Governors. At this juncture, it has be governments and the constitution to the come important to now ask: Of what relevance is the discourse on local governments and the constitution to the whole body of knowledge, and more importantly, to political theory? We here recognize that literature in this particular area of research is both scanty and skeletal. Also, the little information that exist on this, address the intergovernmental relations component such as the excellent work of Gboyega (1981). The discourse has become important in the light of the following:

First, it is here argued that the true test of federalism, its propositions and postulations, rest in a concrete examination of the encroachments that follow the broad constitutional provision in federal systems that empower only the State to legislate on the structure, operations and revenue of the local governments. There is therefore the urgent 
and imperative need to examine the theoretical bases that have informed the practice in real life governmental operations and processes. Second, beyond the import which the discourse serves in appreciating key issues of political theory, especially the rationalization and justification of local government, the legal dimension is as well important in helping to fashion for political systems the right constitutional framework that provides the relevant basis for sustainable development, peace and prosperity.

\section{The Nigerian Experience: Implications for Comparative Research}

The Nigerian experience of the relationship between local government and the constitution obviously has serious implication for comparative research and study. It has, among others, created the basis in which some formulations can be made with respect to the study of cross-national experiences. The fact that the constitution, among others, determines the framework and structure of government means that any comparative study/investigation should begin to look for similarities and dissimilarities in the workings of constitutions, in particular in the relationship between the constitution and local government. The implication which the Nigerian experience poses for comparative research can be better appreciated if we first seek to know the conclusions that were arrived at from our study of the Nigerian experience. The Nigerian experience and or study presents a bad omen for the "federal principle" all over the world, in particular, the federal societies of the Third World. The running, existence and operations of the local governments seem to depend largely on the behest of the executive, especially the Governor with or without the State legislature. In place of "elected local government councils", a constitutional requirement and or provision are new coinages such as "sole administratorship", "transition committees", "caretaker committees", etc. while the constitution and the various laws provide for tenure of three years for local government elected councils, it is either that this is aborted all of sudden, or that they are replaced with "transition or caretaker committees", whichever pleases the political calculation of the Governor or Executive Governor as sometimes called. From the Nigerian experience, local government systematically fits into the permutation of electoral process nationally. For instance, the self-acclaimed biggest party in Africa, the People's Democratic Party (PDP), recently decided that election into the local government councils could only come up not earlier than December, 2007 after the party would have had its National Convention in October, 2007 hopefully. It might be one of the tactics to address the legitimacy crisis which the administration of President Umar Yar'adua currently faces, or a bid to ensure that the PDP is fully entrenched in Nigeria.

The second conclusion of the Nigerian study of the relationship between local government and the constitution is that local government is far from being a tier of government in the strict legal terminology. Until recently when President Umar Yar'adua ordered that the withheld local government funds of Lagos State be immediately released, his predecessor, President Olusegun Obasanjo, in spite of the Supreme Court ruling on the subject, kept hold on the funds for politically related reasons. What is clear from this Nigerian experience is that party differences exert recognizable limitation on the legal status of the local government. Related to this is the fact that where lack of separation exists between government and the ruling party, governmental processes and procedures are compromised to the detriment of due process and constitutional provisions. It is worth 
recalling here that out of the five State Governors that took the federal government to court over the creation of additional local governments at different times before the 2007 General Elections, only ex-Governor Bola Tinubu of Lagos State fought it to the last as the other Governors had to "chicken out", obviously because of the overwhelming power of exPresident Olusegun Obasanjo, either as ex-General or Leader of the People's Democratic Party (PDP).

The question remains: How can the Nigerian experience provide reliable basis for comparative research? In other words, how can the relationship between local government and the constitution provide basis and opportunity for comparative research? Before we shall attempt to provide answers, it is pertinent to emphasize that the relationship between local government and the constitution is not restricted to a federal environment along. But what is the most important to stress is that the relationship between local government and the constitution is better studied in environments whose constitutions are both written and rigid. As these remain significant features of federal political systems, the conclusion is most likely that federal systems are very appropriate for the study.

Important as the Nigerian experience is, the degree of its reliability and dependability for comparative research is however, constrained by the "uniqueness" and peculiarities of the Nigerian environment. Nigeria is perhaps the only country in the world where constitutional provisions are violated and everybody pretends to be unaware or goes to sleep. Second, Nigeria is characterised by uncertainties and inconsistencies. Some still continue to question the framing of the 1999 constitution of the "elective principle" in Nigeria in 1922, democracy in Nigeria is still in its embryo. All these factors tend to limit the opportunity of using the Nigerian case study for the purpose of comparative research. Just as in the specialized field of comparative politics where competing paradigms flood the process of comparative research and investigation, the Nigeria experience with respect to the relationship between local government and the constitution can in spite of the problems identified and discussed above, still provide directions to cross-national research especially in the area of conceptual formulation. Concepts such as "function”, "actor”, "environment”, “input and output”, "stability”, “pattern maintenance”, etc, which already serve the purpose of comparative research in political science can as well be used to either investigate the Nigerian or global experiences. Specifically, we might seek to determine or know the equivalences of "function”, “actor”, etc, of the Nigerian local government system in other political systems of the world.

The Nigerian experience can therefore offer reliable basis and or framework for comparative research. The focus of the comparative research can be placed on questions such as: What should be the relationship, in both theory and practice, between local government and the constitution? Should the constitution necessarily specify a dependent relationship? What specific form and character should the relationship take? Should the relationship be limited to power of establishment, creation and or control, or should be relationship be as defined in the sources of revenue available to each tier of government as specified in the constitution? What consequences and policy implications do the questions above pose either for sustainable democracy or institution-building? The questions though regionally framed, but can however, are extended to other political systems with the view to determining where differences and or variations exist, and what implications arising there from. These, no doubt, constitute the nuclei of comparative research methodology of the social science genre. 


\section{Conclusion}

The paper has set for itself the task of examining the relationship between the local government and the constitution within the Nigerian experience of the theory and practice of federalism. The constitution ever remains a legal framework defining the structure of any government and the relationship between and among the agencies of government, among others. The Nigerian experience is very appealing as the local government is yet to enjoy the status of a tier of government judged by the continuing violation of the constitution which requires that local government should be democratically administered and managed. However, the Nigerian experience provides scholarly opportunities for researching into an obviously neglected area in social science study and analysis. A focus on this area of neglect will no doubt help to rebuild and reframe the thought on local government, in particular its relationships with other tiers of government.

\section{References}

1. Aborishade, O. and Aransi, I.O. (eds.) (2006). State and Local Government in Nigeria: The Changing Scene, Charlotte, North Carolina: Catawba Publishing Co.

2. Adamolekun, L. and Rowland, L. (eds.) (1979). The New Local Government System, Ibadan: Heinemann Educational Books Nig. Ltd

3. Akhakpe, I. (2006). Third-tier of Government and Democracy. In Emmanuel O. Ojo (ed.), Challenges of Sustainable Democracy in Nigeria. Ibadan: John Arches, pp. 72-76

4. Akpomuvire, M. (2004). Customary Law and Traditional Rulership in Nigeria, In Isiaka O.

5. Aransi (ed), Local Government and Culture in Nigeria, Chapel Hill, North Carolina: The Chapel Hill Press Inc., pp. 122-178

6. Brian, C.S (1969). The Justification of Local Government. In Feldman, L.D. and Goldrick, M.D. (eds.), Politics and Government of Urban Canada. Toronto: Methuen, pp. 332-347

7. Campbell, M.J. (1963), Law and Practice of Local Government in Northern Nigeria, Lagos: African University Press.

8. Charles, F.W. (1948). The Foundation of Local Government. In Wilson, C.F. (ed.), Essays on Local Government, Oxford: Basil Blackwell, pp. 1-24.

9. Gboyega, E.A. (1981). Intergovernmental Relations in Nigeria: Local Government and the 1979 Constitution, Public Administration and Development, $1(4): \quad 281-290$ https://doi.org/10.1002/pad.4230010404

10. Georges, L. (1953). Local Government and Democracy. Public Administration, 31(Spring):25-34

11. Harold, J.L. (1967). A Grammar of Politics. London: George Allen \& Unwin.

12. Hugh, W. (1976). Ideology, Democracy and the Foundations of Local Self-Government. In Feldman, L.D. and Goldrick, M.D (eds.), Politics and Government of Urban Canada, Toronto: Methuen

13. Isiaka O. Aransi (2004), Local Government and Culture in Nigeria, op.cit.

14. John, S.M (1975) Consideration of Representative Government. In Mills, J.S. (ed.) Three Essays, London: Oxford University Press, pp. 358-364

15. Julius O. Ihonvbere (1996), “A Radical View of Nigeria’s Political Development”, In Oyediran, O. (ed.), Governance and Development in Nigeria: Essays in Honour of Professor Billy J. Dudley, Ibadan: Oyediran Consult International, pp. 108-134

16. Keith Panter-Brick (1954). Local Government as Basis for Democracy: A Rejoinder, Public Administration, 3(Winter): 438-440. https://doi.org/10.1111/j.1467-9299.1954.tb01217.x

17. Mackenzie, W.J.M. (1961), Theories of Local Government, London: London School of Economics.

18. Nwabueze, S. (1982). The Presidential Constitution of Nigeria. London: Hurst and Co.

19. Nwabueze, S. (1985). Nigeria’s Presidential Constitution 1979-1983. London: Longman

20. Olakanmi O. (2006). The Nigerian Constitutions: 1963, 199 and 1999: A Compendium (2nd ed.), Abuja, Nigeria: Panaf Press. 
21. Mojeed, O.A (2006). Federal -State Relations in Nigeria: Judicial Interpretation. In Ojo, E.O. (ed.), Challenges of Sustainable Democracy in Nigeria, op.cit pp. 235-245

22. Oyediran, O. and Gboyega, E.A (1979), "Local Government and Administration, In Oyediran, O. (ed.), Nigerian Government and Politics under Military Rule (1966-1979), London: Macmillan, pp. 169-191

23. Sharpe, L.J. (1970). Theories and Values of Local Government, Political Studies, 18(2): 153-174 https://doi.org/10.1111/j.1467-9248.1970.tb00867.x

24. Wheare, K.C. (1953) Federal Government 4th ed, London: Oxford University Press 